\title{
Urinary total porphyrins by ion exchange analysis: Reference values for the normal range and remarks on preformed porphyrins in acute porphyria urine
}

\author{
J. FOGSTRUP AND T. K. WITH, \\ WITH THE TECHNICAL ASSISTANCE OF A. KHAN AND A. RAUF \\ From the Departments of Internal Medicine and Clinical Chemistry, Svendborg Hospital, Denmark
}

SUMMARY Determination of total porphyrin with a rapid and easy method (ion exchange; spectrophotometry) was performed on 57 morning urine samples from laboratory personnel, 59 arbitrary day urine samples from blood donors, and 90 24-hour urines from medical inpatients. The upper reference limit for morning urine was $0.32 \mu \mathrm{mol} / 1$ but even a value as high as $0.7 \mu \mathrm{mol} / 1$ was found. In the donor urines the upper limit was $0 \cdot 155 \mu \mathrm{mol} / \mathrm{l}$. The 24-hour urines showed an upper reference limit of $271 \mu \mathrm{g} / 24 \mathrm{~h}$. These values are in good agreement with values from the literature, mostly based on extraction analyses. Tracings of the absorption curves in the region of $380-430 \mathrm{~nm}$ were performed in all analyses and showed that the non-porphyrin absorption was close to linear in most cases. Studies of porphyric urines gave no support to the claim that preformed porphyrins not formed from porphobilinogen are excreted in this disease.

The reference values for urinary porphyrins in the normal range found in the literature are based on various techniques, but primarily on rather timeconsuming solvent extraction methods, while satisfactory reference materials based on the more rapid and simple ion exchange analysis have not been presented. As we have recently (With and Pedersen, 1978) described an easy, rapid, and cheap ion exchange technique for the determination of total porphyrin in urine, we collected reference material of blood donors, laboratory personnel, and medical inpatients with this technique and included tracings of the absorption curve in the range $380-430 \mathrm{~nm}$ to get the best possible check on analytical accuracy.

We also included 10 patients with latent porphyria (acute intermittent type) from our material (With, 1969) to study the role of excretion of preformed porphyrins compared to porphobilinogen in this disease.

\section{Previous studies}

Several authors have published reference values on coproporphyrin based on the extraction technique and a few have used ion exchange chromatography.

Received for publication 2 August 1978
Their results are summarised in Table 1, which shows that all authors gave reference values for total porphyrin of less than $350 \mu \mathrm{g} / 24 \mathrm{~h}$.

\section{Material and methods}

Total porphyrin was determined in the first morning urine of 57 laboratory personnel, 23 men and 34 women aged 20 to 65 years. Similar analyses were made on arbitrary day urine samples from 59 blood donors, 31 men and 28 women aged 18 to 60 years, and on 24-hour urines from 90 medical inpatients (61 men and 29 women), 56 suffering from heart disease (observation for coronary occlusion) and the remainder from diabetes, Addison's disease, Graves' disease, apoplexy, bronchial asthma, or rheumatoid arthritis. Patients with liver and blood diseases and infections were excluded.

The analytical method used was recently described in detail (With and Pedersen, 1978). The readings were performed in a Beckman Model 25 double beam recording spectrophotometer, and in all cases tracings in the region of $380-430 \mathrm{~nm}$ were performed to control the Soret maximum. These tracings give a picture of the linearity of the non-porphyrin absorption in the $380-430 \mathrm{~nm}$ interval, which is a condition for the Rimington-Sveinsson correction on which the calculations are based. One millilitre of urine 109 
Table 1 Previous quantitative studies on porphyrins in normal urine

\begin{tabular}{|c|c|c|c|c|}
\hline Authors & Year & Material & Method & Result (range) \\
\hline Zieve et al. & 1953 & $\begin{array}{l}\text { 24-h urines from normal } \\
\text { men (698) and women }(50)\end{array}$ & $\begin{array}{l}\text { Acetic acid-ethyl acetate- } \mathrm{HCl} \\
\text { extraction with fluorimetric } \\
\text { reading }\end{array}$ & $\begin{array}{l}100-300 \mu \mathrm{g} / 24 \mathrm{~h} \text { for men } \\
200-275 \mu \mathrm{g} / 24 \mathrm{~h} \text { for women }\end{array}$ \\
\hline Gutniak and Dancewicz & 1957 & $\begin{array}{l}\text { 24-h urines from } 100 \text { normal } \\
\text { men }\end{array}$ & Technique of Zieve et al. & $\begin{array}{l}\text { Mean } 132 \pm 50 \mu \mathrm{g} / 24 \mathrm{~h} \\
95 \% \text { limit } 232 \mu \mathrm{g} / 24 \mathrm{~h}\end{array}$ \\
\hline Talman & 1958 & $\begin{array}{l}\text { 24-h urines from } 9 \text { healthy } \\
\text { subjects }\end{array}$ & $\begin{array}{l}\text { Acetic acid-ethyl acetate-HCl } \\
\text { extraction and fluorimetric } \\
\text { reading for coproporphyrin; } \\
\mathrm{Al}_{2} \mathrm{O}_{3} \text { adsorption and } \mathrm{HCl} \\
\text { elution for uroporphyrin }\end{array}$ & $\begin{array}{l}\text { Coproporphyrin: range } 81-222 \text {, } \\
\text { mean } 132 \mu \mathrm{g} / 24 \mathrm{~h} \text {. } \\
\text { Uroporphyrin: range } 28-63 \text {, } \\
\text { mean } 39 \mu \mathrm{g} / 24 \mathrm{~h} \text {. } \\
\text { Total porphyrin: range } 109-285 \text {, } \\
\text { mean } 671 \mu \mathrm{g} / 24 \mathrm{~h} \text {. }\end{array}$ \\
\hline Schwartz et al. & 1960 & No details & As above & $\begin{array}{l}\text { Coproporphyrin } 100-250 \mu \mathrm{g} / 24 \mathrm{~h} \text {; } \\
\text { uroporphyrin } 10-30 \mu \mathrm{g} / 24 \mathrm{~h} ; \\
\text { total porphyrin } 110-280 \mu \mathrm{g} / 24 \mathrm{~h}\end{array}$ \\
\hline Rimington & 1961 & No details & $\begin{array}{l}\text { Fractionate extraction with ether } \\
\text { and cyclohexanone and spectro- } \\
\text { photometric reading of } \mathrm{HCl} \\
\text { extracts }\end{array}$ & $\begin{array}{l}\text { Coproporphyrin } 166 \pm 45 \mu \mathrm{g} / 24 \mathrm{~h} \\
\text { for men, } 134 \pm 42 \text { for women; } \\
\text { uroporphyrin } 5-80 \mu \mathrm{g} / 24 \mathrm{~h} \text { for } \\
\text { both sexes. Total porphyrin } \\
\text { upper limit } 336 \mu \mathrm{g} / 24 \mathrm{~h}\end{array}$ \\
\hline Doss and Schmidt & 1971 & $\begin{array}{l}\text { Random samples from } 95 \\
\text { apparently normal persons } \\
\text { ( } 48 \text { men and } 47 \text { women) }\end{array}$ & $\begin{array}{l}\text { Ion exchange chromatography } \\
\text { with Mills's (1961) method }\end{array}$ & $\begin{array}{l}55 \pm 33 \mu \mathrm{g} / 1 \text { for men and } \\
47 \pm 33 \mu \mathrm{g} / 1 \text { for women, upper } \\
95 \% \text { reference limit } 121 \mu \mathrm{g} / 1\end{array}$ \\
\hline Sobel et al. & 1974 & $\begin{array}{l}\text { 24-h urines from } 48 \text { laboratory } \\
\text { technicians }\end{array}$ & $\begin{array}{l}\text { Ion exchange on a } 200-400 \text { mesh } \\
\text { resin with fractionate extraction } \\
\text { of copro- and uroporphyrin with } \\
\text { ethanol-isopropanol- } \mathrm{HCl} \text { mix- } \\
\text { tures and spectrophotofluori- } \\
\text { metric reading }\end{array}$ & $\begin{array}{l}\text { Coproporphyrin: range } 35-235 \text {, } \\
\text { mean } 117 \mu \mathrm{g} / 24 \mathrm{~h} \text {. Uropor- } \\
\text { phyrin: } 15-60 \text {, mean } 29 \mu \mathrm{g} / 24 \mathrm{~h} \text {. } \\
\text { Total porphyrin: } 50-295 \mu \mathrm{g} / 24 \mathrm{~h}\end{array}$ \\
\hline
\end{tabular}

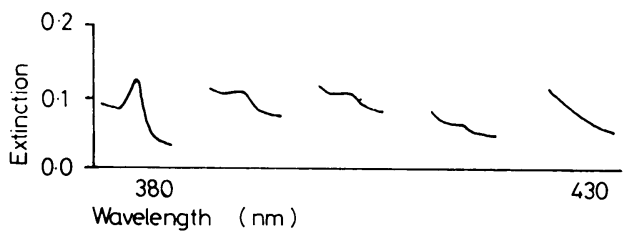

Fig. 1 Five typical tracings: No. 1 shows a typical Soret peak $\left(e^{k}=0 \cdot 140\right)$, No. 2 a low maximum $\left(e^{k}=0.034\right)$, No. 3 a still lower one $\left(e^{k}=0.015\right)$, No. 4 an inflection on a curve with concavity upwards $\left(e^{k}=0.002\right)$, and No. 5 a slightly concave curve without any inflection $\left(e^{k}=0.001\right)$.

was used and eluted with $5 \mathrm{ml} 3 \mathrm{M} \mathrm{HCl}$. Most of the tracings exhibited a maximum or an inflection at $403 \mathrm{~nm}$, the absorption maximum of coproporphyrin in $3 \mathrm{M} \mathrm{HCl}$, and were linear outside the peak but some of the tracings were curved, showing an upward concavity. The corrected extinction $\mathrm{e}^{\mathrm{k}}=2 \times$ $\mathrm{e}^{\max }-\left(\mathrm{e}^{380}+\mathrm{e}^{430}\right)$ corresponding to such curves was often below zero. Typical curves are shown in Figure 1. The readings were converted to micromoles by using the molecular weight of coproporphyrin (654 Daltons).
Table 2 Acute porphyria urine from 15 AIP patients or carriers collected with buffering to $\mathrm{pH}$ 6-7

\begin{tabular}{rll}
\hline$P B G(\mu \mathrm{mol} / \mathrm{l})$ & $\begin{array}{l}\text { Total porphyrin } \\
(\mu \mathrm{mol} / \mathrm{l})\end{array}$ & $\begin{array}{l}\text { Molar ratio \% } \\
\text { Total porphyrin: } P B G\end{array}$ \\
\hline 11 & 0.13 & $1 \cdot 19$ \\
120 & 0.24 & 0.20 \\
10 & 0.07 & 0.75 \\
5 & 0.01 & 0.22 \\
92 & 0.37 & 0.40 \\
194 & 0.57 & 0.31 \\
67 & 0.14 & 0.21 \\
39 & 0.24 & 0.62 \\
227 & 0.35 & 0.15 \\
136 & 0.61 & 0.45 \\
27 & 0.25 & 0.93 \\
650 & 1.61 & 0.25 \\
269 & 0.55 & 0.20 \\
33 & 0.60 & 1.82 \\
7 & 0.06 & 0.85 \\
\hline
\end{tabular}

The urines or our porphyric patients were collected in buffered flasks of $\mathrm{pH} 7$ or above to avoid formation of porphyrin from porphobilinogen (PBG). We studied 15 urines from 15 different carriers of acute hepatic porphyria showing PBG excretion of 5-650 $\mu \mathrm{mol} / \mathrm{litre}$. PBG was determined by Mauzerall and Granick's (1956) method. The results are presented in Table 2. 


\section{Results}

Our results are presented in Figs 2,3 , and $4 a$, b. The maximal value in morning urine $(0.7 \mu \mathrm{mol} / \mathrm{l})$ was found in a healthy female laboratory technician aged 35. To exclude a latent porphyria we determined porphyrins and precursors in another urine sample two weeks later as well as in faeces. These analyses were normal, the total porphyrin being $0.23 \mu \mathrm{mol} / 1$. This shows that normal urinary porphyrin can occasionally reach about twice the $95 \%$ limit (mean + 2 SD).

Our values for morning urine were $0.128 \pm 0.098$, upper reference value $0.322 \mu \mathrm{mol} / 1$, and our day urines of blood donors showed the considerably lower figures $0.075 \pm 0.047$, upper limit 0.155 $\mu \mathrm{mol} / \mathrm{l}$. Our values are only strictly comparable with those of Doss and Schmidt (1971) as all other authors used 24-hour urine. They found a reference limit of $121 \mu \mathrm{g} / \mathrm{l}$, that is, $0 \cdot 185 \mu \mathrm{mol} / \mathrm{l}$, in good agreement with our values for the donor urines.

Our values for 24-hour urines were $67 \pm 52$, upper reference limit $271 \mu \mathrm{g} / 24 \mathrm{~h}$, corresponding reasonably well with the values in the literature where the upper reference limits vary between 230 and $336 \mu \mathrm{g} / 24 \mathrm{~h}$.

Our studies on urines from known porphyric

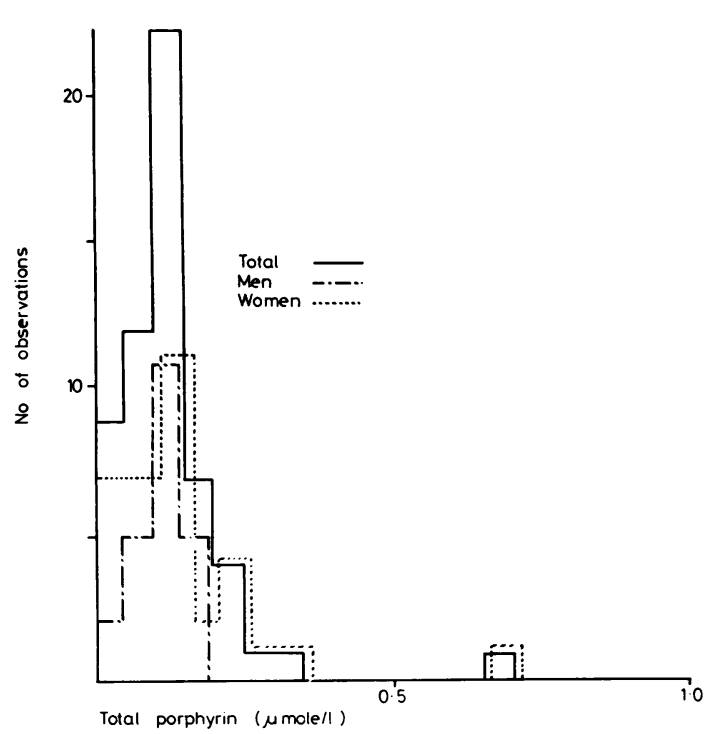

Fig. 2 Total porphyrin in morning urine of 57 persons (laboratory personnel and spouses; 23 men and 34 women):

$\begin{array}{lllll} & \text { Total } & \text { Men } & \text { Women } & \\ \text { mean } & 0.128 & 0.116 & 0.137 & \mu \mathrm{mol} / 1 \\ \sigma & 0.098 & 0.052 & 0.121 & \mu \mathrm{mol} / 1 \\ \mathrm{~m}+2 \sigma & 0.322 & 0.210 & 0.379 & \mu \mathrm{mol} / 1\end{array}$

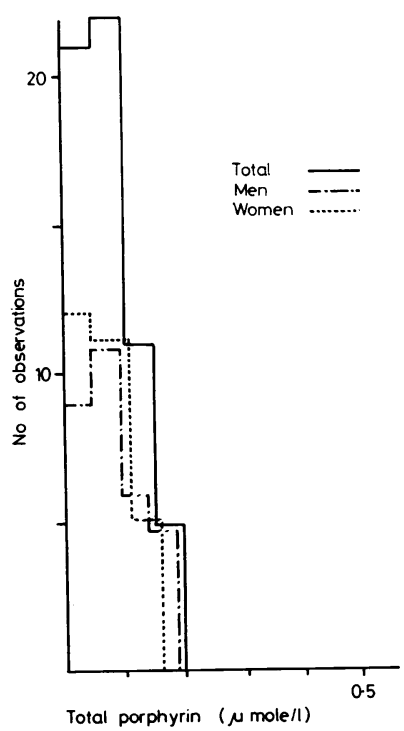

Fig. 3 Total porphyrin in arbitrary voided samples of 59 blood donors, 31 men and 28 women.

$\begin{array}{lllll} & \text { Total } & \text { Men } & \text { Women } & \\ \text { mean } & 0.075 & 0.083 & 0.066 & \mu \mathrm{mol} / 1 \\ \sigma & 0.047 & 0.050 & 0.040 & \mu \mathrm{mol} / 1 \\ \mathrm{~m}+2 \sigma & 0.155 & 0.183 & 0.146 & \mu \mathrm{mol} / 1\end{array}$

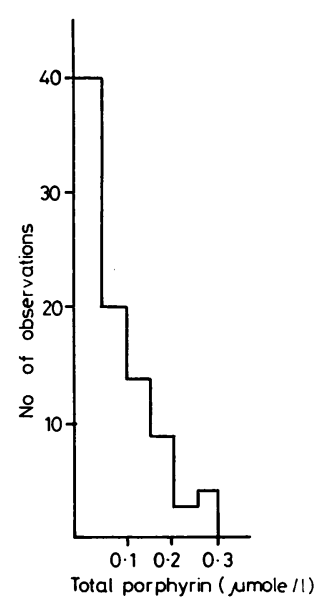

(a)

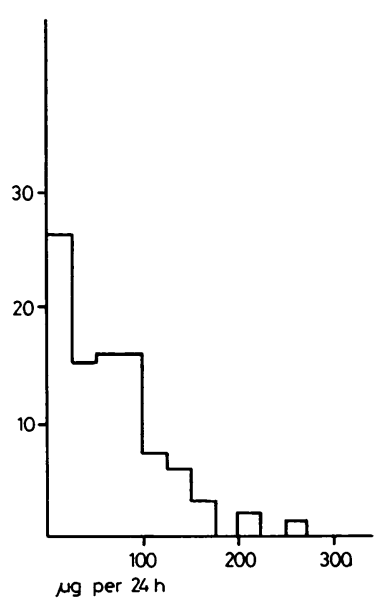

(b)
Fig. 4 Total porphyrin in 24-hour urine from 90 medical inpatients.

$\begin{array}{llllrl}(a) & & & (b) & \\ \text { mean } & 0.084 & \mu \mathrm{mol} / 1 & \text { mean } & 67 & \mu \mathrm{g} / 24 \mathrm{hr} \\ \sigma & 0.070 & \mu \mathrm{mol} / 1 & \sigma & 52 & \mu \mathrm{g} / 24 \mathrm{hr} \\ \mathrm{m}+2 \sigma & 0.224 & \mu \mathrm{mol} / 1 & \mathrm{~m}+2 \sigma & 271 & \mu \mathrm{g} / 24 \mathrm{hr}\end{array}$

carriers (Table 2) comprised 15 urines from different patients with a PBG content ranging from normal up to five times the upper normal limit. In all 
instances the molar ratio total porphyrin:PBG was below $2 \%$, and if PBG was above $50 \mu \mathrm{mol} / 1$ the molar ratio was always below $1 \%$.

\section{Discussion}

As will be seen from the tracings in Fig. 1, it is meaningless to speak of a lower limit for normal urinary porphyrin because our absorption curves in several cases showed only faint inflections in the Soret region and occasionally were not linear, giving negative corrected extinctions. We have tried to get higher Soret peaks by using $5 \mathrm{ml}$ of urine instead of $1 \mathrm{ml}$; but in urines without definite peaks the only result was an increase in the non-specific background absorption. As the analysis is more rapid with $1 \mathrm{ml}$ urine we used this in our investigations.

Our results do not support the claim of Doss and Schermuly (1976) that preformed porphyrins exceeding normal excretion occur in porphyric urines because only one of our urines, with $650 \mu \mathrm{mol}$ PBG per litre, showed excretion exceeding our upper normal reference limit for total porphyrin. Therefore further documentation on urines from acute porphyric patients with high PBG excretion collected at pH 7 or above is required to substantiate the claim that preformed porphyrins are excreted in excess during the porphyric attack.

Our work was supported by grant no. 512-7050 from the Medical Research Council of the Danish State and by grants to A. Khan and A. Rauf from the Danish International Development Agency.

\section{References}

Doss, M., and Schmidt, A. (1971). Rapid determination of urinary total porphyrins by ion-exchange chromato- graphy. Zeitschrift für klinische Chemie und klinische Biochemie, 9, 415-418.

Doss, M., and Schermuly, E. (1976). Urinary porphyrin excretion pattern and isomer distribution of I and III in human porphyric disorders. In Porphyrins in Human Diseases, edited by M. Doss, pp. 189-204. Karger, Basle.

Gutniak, O., and Dancewicz, A. M. (1957). The normal excretion variability of urinary coproporphyrin in healthy men (in Polish). Medycyna Pracy, 8, 411-420.

Mauzerall, D., and Granick, S. (1956). The occurrence and determination of delta-aminolevulinic acid and porphobilinogen in urine. Journal of Biological Chemistry, 219, 435-446.

Mills, G. C. (1961). Routine analysis of porphyrins in urine. Clinical Chemistry, 7, 165-174.

Rimington, C. (1961). Quantitative determination of porphobilinogen and porphyrins in urine and faeces. Broadsheet no. 36. Association of Clinical Pathologists, London.

Schwartz, S., Berg, M. H., Bossenmaier, I., and Dinsmore, H. (1960). Determination of porphyrins in biological materials. Methods of Biochemical Analysis, 8, 221-293.

Sobel, C., Cano, C., and Thiers, R. E. (1974). Separation and quantitation of coproporphyrin and uroporphyrin in urine. Clinical Chemistry, 20, 1397-1402.

Talman, E. L. (1958). Porphyrins in urine. In Standard Methods of Clinical Chemistry, edited by D. Seligson, Vol. 2, pp. 137-146. Academic Press, New York.

With, T. K. (1969). Hereditary hepatic porphyrias. Acta Medica Scandinavica, 186, 117-124.

With, T. K., and Pedersen, J. S. (1978). Ion exchange analysis of porphyrins in urine. Scandinavian Journal of Clinical and Laboratory Investigation, 38, 279-284.

Zieve, L., Hill, E., Schwartz, S., and Watson, C. J. (1953). Normal limits of urinary coproporphyrin excretion determined by an improved method. Journal of Laboratory and Clinical Medicine, 41, 663-669.

Requests for reprints to: Dr T. K. With, Department of Clinical Chemistry, Svendborg Sygehus, 5700 Svendborg, Denmark. 